\title{
Role of Glycosides as Epithelial Cell Receptors for Candida albicans
}

\author{
By IAN A. CRITCHLEY AND L. JULIA DOUGLAS* \\ Department of Microbiology, University of Glasgow, Garscube Estate, Bearsden, \\ Glasgow G61 1QH, UK
}

(Received 30 July 1986; revised 17 October 1986)

\begin{abstract}
The effect of various lectins and sugars on adhesion of five strains of Candida albicans to buccal and vaginal epithelial cells in vitro was investigated. Adhesion of C. albicans GDH 2346 was inhibited primarily by L-fucose and winged-pea lectin, whereas adhesion of strain GDH 2023 was inhibited by $N$-acetyl-D-glucosamine, or D-glucosamine, and wheat-germ agglutinin. Three other strains of $C$. albicans (MRL 3153, GRI 681 and GRI 682) gave results similar to those obtained with strain GDH 2346. Extracellular polymeric material (EP) isolated from strain GDH 2346 inhibited adhesion of strains MRL 3153, GRI 681 and GRI 682 by more than $50 \%$, but that of strain GDH 2023 by only 30\%. EP from strain GDH 2023 had little or no effect on the adhesion of any other yeast strain. Lectin-like proteins with affinities for L-fucose, $N$-acetylD-glucosamine and D-mannose were detected in EP from all five strains in different amounts. These results indicate that there are at least two types of adhesion mechanism and that glycosides containing L-fucose or $N$-acetyl-D-glucosamine can function as epithelial cell receptors for $C$. albicans.
\end{abstract}

\section{INTRODUCTION}

A variety of different experimental approaches have been used in attempts to identify the yeast adhesin(s) responsible for attachment of Candida albicans to epithelial cells, and there is now considerable evidence that surface mannoprotein fulfils this role (see Douglas, 1985, 1987). In the preceding paper (Critchley \& Douglas, 1987), we described the partial purification of an adhesin from extracellular polymeric material (EP) isolated from yeast culture supernatants, and provided evidence that the protein portion of the mannoprotein adhesin is more important than the carbohydrate moiety in mediating attachment to buccal cells.

Rather less information is available on the nature of the epithelial cell receptor(s) for $C$. albicans. Involvement of the protein portion of yeast mannoprotein in the attachment process would be analogous to many bacterial adhesion mechanisms where a proteinaceous adhesin binds to a glycoside receptor (either glycoprotein or glycolipid) on the host cell surface (Jones \& Isaacson, 1983). Different sugars have been reported to inhibit adhesion of $C$. albicans to buccal (Sandin et al., 1982; Collins-Lech et al., 1984), vaginal (Sobel et al., 1981; Segal et al., 1982) and uro-epithelial cells (Centeno et al., 1983), as well as to corneocytes (Collins-Lech et al., 1984). However, the results of these studies have proved contradictory and the identity of the epithelial cell receptor(s) remains unclear. The present paper describes an investigation of the possible role of glycosides in the adhesion of five $C$. albicans strains to buccal and vaginal epithelial cells in vitro. Three of these strains (I strains) were isolated originally from active infections, while two (C strains) came from asymptomatic carriers (McCourtie \& Douglas, 1984).

\section{METHODS}

Organisms. Five strains of C. albicans were used in this study. C. albicans MRL 3153 was from the Mycological Reference Laboratory at the London School of Hygiene and Tropical Medicine, London, UK. The remaining four strains were isolated in Glasgow and are now deposited with the National Collection of Yeast Cultures (NCYC),

Abbreviations: Con A, concanavalin A; EP, extracellular polymeric material. 
Food Research Institute, Norwich, UK. Strains GRI 681 (NCYC 1472) and GRI 682 (NCYC 1473) were obtained from routine cervical smears taken from asymptomatic women at Glasgow Royal Infirmary; strains GDH 2346 (NCYC 1467) and GDH 2023 (NCYC 1468) were isolated at Glasgow Dental Hospital from patients with denture stomatitis. The organisms were maintained on slopes of Sabouraud dextrose agar (Difco) and subcultured monthly. Every two months the cultures were replaced by new ones freshly grown from freeze-dried stocks.

Growth conditions. The yeasts were grown at $37^{\circ} \mathrm{C}$, with shaking, in yeast nitrogen base medium (Difco) containing $500 \mathrm{~mm}$-galactose as described by McCourtie \& Douglas (1981). Cells were harvested after $24 \mathrm{~h}$ (stationary phase of growth) and washed twice in $0.15 \mathrm{M}$-phosphate-buffered saline, pH 7.2 (PBS).

Isolation of EP. Yeasts were grown for $5 \mathrm{~d}$ in yeast nitrogen base medium containing $500 \mathrm{~mm}$-galactose, and crude EP was isolated from dialysed culture supernatants as described in the accompanying paper (Critchley \& Douglas, 1987).

Adhesion assays. Yeast adhesion to buccal or vaginal epithelial cells was determined by light microscopy as

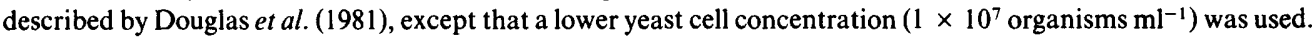
Exfoliated buccal or vaginal cells were obtained from the mucosal surface of a single healthy human donor in each case. All adhesion values quoted represent mean figures derived from three independent assays done in triplicate. For some experiments the standard assay procedure was modified as follows.

(i) Pretreatment of epithelial cells with lectins or EP. Lectins were used at a concentration of $100 \mu \mathrm{g} \mathrm{ml}^{-1}$ in $0.05 \mathrm{M}$ Tris/saline buffer ( $\mathrm{pH} 7 \cdot 2$ ), containing $\mathrm{CaCl}_{2}, \mathrm{MnCl}_{2}$ and $\mathrm{MgCl}_{2}$ (each $0.002 \mathrm{M}$ ). The lectins (all from Sigma) were: concanavalin A (Con A) (from Canavalia ensiformis; specific for terminal $\alpha$-D-mannosyl and $\alpha$-D-glucosyl residues); lentil lectin (from Lens culinaris; specific for terminal $\alpha$-D-mannosyl and $\alpha$-D-glucosyl residues); wheatgerm agglutinin (from Triticum vulgaris; specific for $N$-acetyl- $\beta$-D-glucosaminyl residues and $N$-acetyl- $\beta$-Dglucosamine oligomers); peanut lectin (from Arachis hypogaea; specific for D-galactosyl residues); winged-pea lectin (from Lotus tetragonolobus; specific for $\alpha$-L-fucosyl residues). EP was used at a concentration of $10 \mathrm{mg} \mathrm{ml}^{-1}$ in PBS. Washed epithelial cell suspensions $\left(1 \times 10^{5}\right.$ cells $\mathrm{ml}^{-1}$ in PBS; $\left.1 \mathrm{ml}\right)$ were centrifuged in a Beckman microfuge and the pellet was resuspended in a solution of lectin or EP $(1 \mathrm{ml})$. After incubation at $37^{\circ} \mathrm{C}$ for $30 \mathrm{~min}$ with gentle shaking, the epithelial cells were recovered by centrifugation and resuspended in PBS ( $1 \mathrm{ml})$ for use in adhesion assays.

(ii) Assay mixtures containing sugars. All sugars (from Sigma) were used at a concentration of $25 \mathrm{mg} \mathrm{ml}^{-1}$ in PBS. Washed epithelial cell suspensions $\left(1 \times 10^{5}\right.$ cells $\mathrm{ml}^{-1}$ in PBS; $\left.1 \mathrm{ml}\right)$ and washed yeast suspensions $\left(1 \times 10^{7}\right.$ organisms $\mathrm{ml}^{-1}$ in PBS; $1 \mathrm{ml}$ ) were centrifuged in a Beckman microfuge and the pellets were resuspended in sugar solution $(1 \mathrm{ml})$. These suspensions were then used in adhesion assays.

Isolation of lectin-like components from $E P$. Various sugars ( $N$-acetyl-D-glucosamine, $N$-acetyl-D-galactosamine, L-fucose, D-galactose, D-mannose and $N$-acetylneuraminic acid; all from Sigma) were coupled to epoxy-activated Sepharose 6B (Sigma). The coupling procedure involved swelling epoxy-activated Sepharose $(1 \mathrm{~g})$ in distilled water for $15 \mathrm{~min}$, and then washing the gel on a sintered glass filter with more distilled water $(100 \mathrm{ml})$. Ligand solution ( $50 \mathrm{mg}$ sugar $\mathrm{ml}^{-1} ; 3 \mathrm{ml}$ ) was mixed with the gel suspension and incubated at $37^{\circ} \mathrm{C}$ for $16 \mathrm{~h}$ in a shaking water bath. Excess sugar was removed by washing with distilled water $(100 \mathrm{ml}), 0 \cdot 1 \mathrm{M}$-sodium bicarbonate buffer, pH 8.0 $(100 \mathrm{ml})$ and $0 \cdot 1 \mathrm{M}$-sodium acetate buffer, $\mathrm{pH} 4.0(100 \mathrm{ml})$. Any remaining reactive groups on the gel were blocked by treatment with $1 \mathrm{M}$-ethanolamine $(5 \mathrm{ml})$ at room temperature overnight. The gel was finally washed with PBS and then transferred to a small column $(100 \times 7 \mathrm{~mm})$. EP $\left(10 \mathrm{mg} \mathrm{ml}^{-1}\right.$ in PBS; $\left.1 \mathrm{ml}\right)$ was applied and the column was eluted with PBS. The protein contents of the EP solution and eluate were determined by the Lowry method so that the percentage of EP protein bound to the gel could be calculated. Bound material was eluted with a solution of the appropriate sugar $\left(25 \mathrm{mg} \mathrm{ml}^{-1} ; 5 \mathrm{ml}\right)$ and the eluate was dialysed against PBS at $4{ }^{\circ} \mathrm{C}$ for $24 \mathrm{~h}$.

\section{RESULTS}

\section{Effect of lectins on adhesion to buccal cells}

Buccal epithelial cells were treated with various lectins of known sugar specificity in an attempt to block possible glycoside receptors for $C$. albicans. Winged-pea lectin inhibited adhesion of $C$. albicans GDH 2346 by more than $40 \%$ (Table 1), suggesting that a glycoside containing $\alpha$-L-fucosyl residues might function as a receptor for this strain. On the other hand, pretreatment with wheat-germ agglutinin (specific for $N$-acetyl- $\beta$-D-glucosaminyl residues) or peanut lectin (specific for D-galactosyl residues) had little effect. By contrast, adhesion of strain GDH 2023 was most efficiently inhibited by wheat-germ agglutinin and was unaffected by either peanut lectin or winged-pea lectin (Table 1). Adhesion of both $C$. albicans strains was considerably enhanced by Con A and lentil lectin. Both of these lectins are known to have more than one binding site and presumably can promote adhesion by acting as bridges between $\alpha$-Dmannosyl residues on the yeast and epithelial surfaces. 
Table 1. Effect of lectins on adhesion of C. albicans GDH 2346 and GDH 2023 to buccal epithelial cells

Buccal epithelial cells were incubated at $37^{\circ} \mathrm{C}$ for $30 \mathrm{~min}$ in PBS or in a solution $\left(100 \mu \mathrm{g} \mathrm{ml}^{-1}\right)$ of lectin. After this pretreatment, buccal cells were recovered by centrifugation, resuspended in PBS and used in adhesion assays. The source and sugar specificity of each lectin are given in Methods.

\begin{tabular}{clccc} 
Strain & \multicolumn{1}{c}{ Lectin } & $\begin{array}{c}\text { Mean no. ( } \pm \text { SEM) of } \\
\text { adherent yeasts per } \\
100 \text { epithelial cells }\end{array}$ & $\begin{array}{c}\text { Relative } \\
\text { adhesion* }\end{array}$ & $\begin{array}{c}P \dagger \\
\text { GDH 2346 }\end{array}$ \\
& Con A & $1508 \pm 71$ & 139 & $<0.001$ \\
& Lentil lectin & $1367 \pm 33$ & 126 & $<0.001$ \\
& Wheat-germ agglutinin & $1005 \pm 124$ & 92 & NS \\
& Peanut lectin & $933 \pm 94$ & 86 & NS \\
& Winged-pea lectin & $623 \pm 107$ & 57 & $<0.001$ \\
GDH 2023 (PBS control) & Con A & $1088 \pm 90$ & 100 & - \\
& Lentil lectin & $1528 \pm 76$ & 126 & $<0.001$ \\
& Wheat-germ agglutinin & $1697 \pm 27$ & 139 & $<0 \cdot 001$ \\
& Peanut lectin & $949 \pm 67$ & 78 & $<0 \cdot 001$ \\
& Winged-pea lectin & $1162 \pm 69$ & 95 & NS \\
& None (PBS control) & $1171 \pm 79$ & 96 & NS
\end{tabular}

* Adhesion is expressed as a percentage of that to control (PBS-treated) epithelial cells for each strain.

† Probability values comparing adhesion to lectin-treated epithelial cells with that to PBS-treated cells. NS, Not significant.

Table 2. Effect of sugars on adhesion of C. albicans GDH 2346 and GDH 2023 to buccal epithelial cells

All sugars were included in standard adhesion assay mixtures at a concentration of $25 \mathrm{mg} \mathrm{ml}^{-1}$.

\begin{tabular}{|c|c|c|c|c|}
\hline \multirow[b]{2}{*}{ Sugar } & \multicolumn{2}{|c|}{ Strain GDH 2346} & \multicolumn{2}{|c|}{ Strain GDH 2023} \\
\hline & $\begin{array}{c}\text { Relative } \\
\text { adhesion* }\end{array}$ & $P \dagger$ & $\begin{array}{c}\text { Relative } \\
\text { adhesion* }\end{array}$ & $P \dagger$ \\
\hline L-Fucose & 71 & $<0.001$ & 103 & NS \\
\hline D-Fucose & 83 & $<0.01$ & 94 & NS \\
\hline D-Galactose & 98 & NS & 107 & NS \\
\hline D-Glucose & 119 & $<0.02$ & 104 & NS \\
\hline D-Mannose & 93 & NS & 83 & $<0.01$ \\
\hline D-Mannosamine & 102 & NS & 86 & $<0.02$ \\
\hline D-Glucosamine & 110 & NS & 66 & $<0.001$ \\
\hline$N$-Acetyl-D-glucosamine & 83 & $<0.05$ & 68 & $<0.001$ \\
\hline None (PBS control) & 100 & - & 100 & - \\
\hline
\end{tabular}

* Adhesion is expressed as a percentage of that in control mixtures for each strain. Control values were $898 \pm$ 120 (mean \pm SEM) and $1163 \pm 31$ adherent yeasts per 100 epithelial cells for strains GDH 2346 and GDH $202 \overline{3}$, respectively.

$\dagger$ Probability values comparing adhesion in the presence of sugar with that in control mixtures. Ns, Not significant.

\section{Effect of sugars on adhesion to buccal cells}

When various sugars were included in adhesion assay mixtures, the results closely paralleled those obtained in the experiments with lectins. L-Fucose inhibited adhesion of $C$. albicans GDH 2346 more efficiently than any other sugar tested but had no effect on adhesion of strain GDH 2023 to buccal cells (Table 2). On the other hand, adhesion of strain GDH 2023 was inhibited quite substantially by $N$-acetyl-D-glucosamine and D-glucosamine and to a lesser extent by D-mannosamine and D-mannose. $N$-Acetyl-D-glucosamine also slightly inhibited adhesion of $C$. albicans GDH 2346. The increased adhesion of this strain observed in the presence of glucose (Table 2) may have been due to a metabolic effect resulting from utilization 
Table 3. Effect of principal inhibitory sugars and lectins on adhesion of C. albicans GDH 2346 and GDH 2023 to vaginal epithelial cells

Vaginal epithelial cells were incubated at $37^{\circ} \mathrm{C}$ for $30 \mathrm{~min}$ in PBS or in a solution $\left(100 \mu \mathrm{g} \mathrm{ml}^{-1}\right)$ of lectin. After this pretreatment, vaginal cells were recovered by centrifugation, resuspended in PBS and used in adhesion assays. Sugars $\left(25 \mathrm{mg} \mathrm{m}^{-1}\right)$ were included in standard adhesion assay mixtures.

\begin{tabular}{clccc} 
Strain & \multicolumn{1}{c}{$\begin{array}{c}\text { Mean no. ( } \pm \text { SEM) of } \\
\text { adherent yeasts per } \\
\text { 100 epithelial cells }\end{array}$} & $\begin{array}{c}\text { Relative } \\
\text { adhesion* }\end{array}$ & $\begin{array}{c}P \dagger \\
\text { GDH } 2346\end{array}$ \\
& L-Fucose & $672 \pm 41$ & 70 & $<0.001$ \\
& $N$-Acetyl-D-glucosamine & $951 \pm 48$ & 99 & $\mathrm{NS}$ \\
& Winged-pea lectin & $701 \pm 28$ & 73 & $<0.001$ \\
& Wheat-germ agglutinin & $839 \pm 59$ & 87 & $\mathrm{NS}$ \\
GDH 2023 & None (PBS control) & $959 \pm 24$ & 100 & - \\
& L-Fucose & $1082 \pm 13$ & 98 & $\mathrm{NS}$ \\
& N-Acetyl-D-glucosamine & $615 \pm 33$ & 56 & $<0.001$ \\
& Winged-pea lectin & $1024 \pm 45$ & 93 & $\mathrm{NS}$ \\
& Wheat-germ agglutinin & $756 \pm 37$ & 69 & $<0.001$ \\
& None (PBS control) & $1101 \pm 16$ & 100 & -
\end{tabular}

* Adhesion is expressed as a percentage of that in control mixtures for each strain.

$\dagger$ Probability values comparing adhesion in the presence of lectin or sugar with that in control mixtures. NS, Not significant.

of the sugar during incubation. Overall, these experiments with sugars and lectins seem to indicate that the major interaction of $C$. albicans GDH 2346 with buccal cells involves fucosecontaining receptors, whereas that of strain GDH 2023 requires receptors containing $N$ acetylglucosamine. Analogous experiments with three other $C$. albicans strains (MRL 3153, GRI 681 and GRI 682) suggested that these strains, like $C$. albicans GDH 2346, adhere to buccal cells principally via fucose-containing receptors (data not shown).

\section{Effect of sugars and lectins on adhesion to vaginal cells}

Similar results were obtained in assays with human vaginal epithelial cells. Adhesion of $C$. albicans GDH 2346 to vaginal cells was significantly inhibited by L-fucose and winged-pea lectin but was unaffected by $N$-acetyl-D-glucosamine and wheat-germ agglutinin (Table 3 ). With strain GDH 2023, however, adhesion was inhibited by up to $44 \%$ by $N$-acetyl-D-glucosamine and wheat-germ agglutinin, while L-fucose and winged-pea lectin had no significant effect. These results suggest that the mechanism of adhesion with either strain is similar for both buccal and vaginal epithelial cells.

\section{Effect of EP on adhesion}

C. albicans GDH 2346 and other I strains are more adherent to epithelial cells than are the C strains GRI 681 and GRI 682 after growth in medium containing 500 mM-galactose (McCourtie \& Douglas, 1984). EP from galactose-grown C strains inhibited adhesion of the homologous yeast by $25-30 \%$ in each case (Table 4), but had little effect on adhesion of strains GDH 2346 and MRL 3153 to buccal cells. However, EP preparations from strains GDH 2346 and MRL 3153 were efficient inhibitors of C-strain adhesion. Since all four strains seem to share a common adhesion mechanism involving fucose-containing receptors, the lack of general inhibition by EP from $C$ strains may reflect a lower proportion of yeast adhesin in EP preparations from these less adhesive yeasts. Table 4 shows that the third I strain used in this study, C. albicans GDH 2023, gave a pattern of results strikingly different from the rest. Adhesion of strain GDH 2023 was substantially inhibited only by the homologous EP preparation and, to a lesser extent, by that from strain GDH 2346. Moreover, EP from this yeast failed to give significant inhibition of adhesion with any other C. albicans strain tested. These results are consistent with those from our experiments with sugars and lectins which pointed to a different adhesion mechanism for this strain. 
Table 4. Effect of different EP preparations on adhesion of five C. albicans strains to buccal epithelial cells

Buccal epithelial cells were incubated at $37^{\circ} \mathrm{C}$ for $30 \mathrm{~min}$ in PBS or in a solution of EP ( $\left.10 \mathrm{mg} \mathrm{ml}^{-1}\right)$ prepared from one of the five $C$. albicans strains as indicated. After this pretreatment, buccal cells were recovered by centrifugation, resuspended in PBS and used in adhesion assays.

\begin{tabular}{|c|c|c|c|c|c|}
\hline \multirow{2}{*}{$\begin{array}{l}\text { Source of EP } \\
\text { used in assay } \\
\text { (strain no.) }\end{array}$} & \multicolumn{5}{|c|}{$\begin{array}{l}\text { Percentage inhibition of adhesion of } \\
\text { C. albicans } \text { strain* }\end{array}$} \\
\hline & GRI 681 & GRI 682 & MRL 3153 & GDH 2346 & GDH 2023 \\
\hline GRI 681 & $25 \cdot 0$ & $5 \cdot 6$ & $0 \cdot 0$ & $2 \cdot 1$ & $3 \cdot 3$ \\
\hline GRI 682 & $0 \cdot 0$ & $29 \cdot 0$ & $2 \cdot 7$ & 3.5 & $14 \cdot 8$ \\
\hline MRL 3153 & $46 \cdot 1$ & $46 \cdot 3$ & $56 \cdot 8$ & $30 \cdot 5$ & 13.7 \\
\hline GDH 2346 & $60 \cdot 1$ & $59 \cdot 2$ & $50 \cdot 8$ & $50 \cdot 0$ & $30 \cdot 8$ \\
\hline GDH 2023 & $12 \cdot 2$ & 6.9 & $0 \cdot 0$ & $0 \cdot 0$ & $55 \cdot 5$ \\
\hline
\end{tabular}

* Inhibition obtained with EP-treated epithelial cells when compared with adhesion to PBS-treated epithelial cells.

Table 5. Isolation of lectin-like components from EP

\begin{abstract}
Samples of EP (10 $\left.\mathrm{mg} \mathrm{m}^{-1}\right)$ were applied to sugar-Sepharose affinity columns prepared from epoxyactivated Sepharose 6B. The percentage of total EP protein bound to each column was determined as described in Methods. Results represent means \pm SEM of two independent determinations where assays were done in duplicate.
\end{abstract}

\begin{tabular}{lrrr} 
& \multicolumn{3}{c}{ EP from strain: } \\
\cline { 2 - 4 } Immobilized sugar & GDH 2346 & GRI 681 & GDH 2023 \\
L-Fucose & $32 \cdot 0 \pm 4 \cdot 3$ & $16.3 \pm 3 \cdot 1$ & $8 \cdot 1 \pm 0.9$ \\
D-Mannose & $18.1 \pm 2 \cdot 1$ & $13.9 \pm 2.6$ & $32.7 \pm 3 \cdot 1$ \\
$N$-Acetyl-D-glucosamine & $6.9 \pm 0.8$ & $4.9 \pm 0.8$ & $15.5 \pm 1 \cdot 5$
\end{tabular}

\title{
Isolation of lectin-like components from EP
}

To investigate the presence of different lectin-like adhesins in C. albicans, EP preparations from all five strains were applied to affinity columns containing various sugars immobilized on Sepharose. The proportion of EP protein bound to each column was then determined. None of the EP preparations contained protein capable of binding to immobilized $N$-acetyl-Dgalactosamine, and only EP from strain GDH 2023 had small amounts of protein which bound to D-galactose and $\mathrm{N}$-acetylneuraminic acid. However, all five EP preparations contained significant proportions of lectin-like protein with binding specificities for L-fucose, D-mannose and $N$-acetyl-D-glucosamine. With $C$. albicans GDH 2346, for example, $32 \%$ of the total EP protein bound to immobilized L-fucose, while $18 \%$ bound to D-mannose and $7 \%$ bound to $N$ acetyl-D-glucosamine (Table 5). Rather less EP protein from the C strain GRI 681 bound to the affinity columns although, again, fucose-binding protein was most abundant and $\mathrm{N}$ acetylglucosamine-binding protein was least abundant. A similar distribution of sugar-binding specificity was observed with EP preparations from strains MRL 3153 and GRI 682 (data not shown). By contrast, most of the bound protein in EP from C. albicans GDH 2023 was associated with D-mannose and least with L-fucose, although with this strain, a significant proportion $(16 \%)$ bound to $N$-acetyl-D-glucosamine (Table 5 ).

In preliminary experiments aimed at characterizing these various lectin-like components, we have shown that all of them contain carbohydrate as well as protein. We have also investigated the ability of each fraction to inhibit adhesion of the yeast strain from which it was derived. Predictably, in assays with strains GDH 2346, MRL 3153, GRI 681 and GRI 682, maximum inhibition was obtained with the fraction having a binding specificity for L-fucose. Surprisingly, however, adhesion of $C$. albicans GDH 2023 was also inhibited most by this fraction. 
Sugar or 'hapten' inhibition tests have been widely used in characterizing epithelial cell receptors for bacteria, and a number of these receptors have now been identified as carbohydrate constituents of membrane glycoproteins or glycolipids (Sharon et al., 1981; Jones $\&$ Isaacson, 1983). When used in isolation, however, such tests have several disadvantages. They can provide equivocal results if the sugar being tested could be regarded as a potential analogue of the adhesin as well as the receptor. With yeast adhesion, for example, mannose-containing components on both cell surfaces might participate in adhesion. Moreover, some sugars can be rapidly metabolized during the assay by the micro-organism under investigation, and this may lead to spurious results. These difficulties could partly explain why previous tests of this type with $C$. albicans have yielded a variety of apparently contradictory data. L-Fucose (Sobel et al., 1981), amino sugars (Segal et al., 1982; Collins-Lech et al., 1984) and D-mannose (Sandin et al., 1982; Centeno et al., 1983) have all been identified in different studies as the major inhibitor of adhesion and hence the likely receptor determinant, whereas other investigators have failed to observe inhibition with any sugar (Lee \& King, 1983; Reinhart et al., 1985). In some instances, the yeast was not tested against the full range of sugars known to be constituents of epithelial cell membranes. However, in the light of the present study, it is probably also significant that all of these earlier investigations appear to have been conducted with a single strain of $C$. albicans, usually a clinical isolate.

Our results indicate that glycosides containing L-fucose, $N$-acetyl-D-glucosamine and possibly D-mannose can all function as epithelial receptors for different strains of $C$. albicans. Of the five strains examined in this study, four appeared to interact primarily with fucose-containing receptors while one (strain GDH 2023) bound via receptors containing $N$-acetylglucosamine. Moreover, the mechanism of attachment in each case was similar for both buccal and vaginal epithelial cells. A strain of $C$. albicans responsible for an outbreak of systemic candidosis (Burnie et al., 1985) also appears to adhere via fucose-containing receptors (unpublished results). Our limited survey therefore suggests that this type of receptor may be most commonly required for C. albicans. L-Fucose (6-deoxy-L-galactopyranose) has not been reported in the cell wall of $C$. albicans but is an important constituent monosaccharide of epithelial cell membranes and appears to function as a major receptor determinant for Vibrio cholerae (Jones \& Freter, 1976) and for some Campylobacter species (Cinco et al., 1984). Adhesion of these bacteria, like that of C. albicans GDH 2346 (Table 2), was only partially inhibited by L-fucose, suggesting that the natural mucosal receptor is larger than an L-fucose residue and/or that a particular stereochemical configuration is required. An alternative possibility for all three organisms is that additional adhesion mechanisms operate. Our results (Table 2) suggest that, for C. albicans GDH 2346, a second system might involve $N$-acetylglucosamine-containing receptors. Similarly, with $C$. albicans GDH 2023, whose major receptor determinant appears to be $\mathrm{N}$ acetylglucosamine, an additional system might operate via D-mannoside receptors.

Our evidence for at least two major types of adhesion mechanism in different $C$. albicans strains is based both on sugar inhibition tests and on experiments with lectins. Because of their high sugar specificity, lectins are frequently used as experimental tools in studies on microbial adhesion. In this investigation, experiments with lectins yielded results which were generally in good agreement with those of the sugar inhibition tests, although the ability of Con A and lentil lectin to enhance adhesion (Table 1) was initially rather unexpected. Both of these lectins possess more than one sugar-binding site (Sharon \& Lis, 1972) and presumably can promote adhesion by cross-linking D-mannosyl residues on yeast and epithelial surfaces. Con A has also been shown to enhance adhesion of $C$. albicans to neutrophils (Diamond \& Krzesicki, 1978), HeLa cells (Makrides \& MacFarlane, 1983) and vascular endothelial cells (Rotrosen et al., 1985). In contrast, Sandin et al. (1982) reported that Con A inhibited adhesion of formaldehyde-killed germinated yeasts to buccal epithelial cells. It has been suggested (Rotrosen et al., 1985) that this discrepancy may be explained by the finding that Con A will bind, but not cross-link, aldehydefixed cells.

Further evidence for the ability of $C$. albicans to participate in multiple types of adhesive interaction came from the detection of several lectin-like proteins in EP preparations. EP from all five strains contained protein capable of binding to L-fucose, D-mannose and $N$-acetyl-D- 
glucosamine, but the proportion of each type varied from one strain to another. Although EP from the four strains with a predilection for L-fucoside receptors contained fucose-binding protein in the greatest amount, EP from strain GDH 2023 seemed to possess less $N$ acetylglucosamine-binding protein than might have been anticipated. However, the relative abundance of these proteins is likely to be less important than their accessibility on the yeast surface. There may also be subtle differences in receptor specificity. EP from strain GDH 2023 did not significantly inhibit adhesion of any other strain (Table 4), suggesting that the precise receptor specificity of its fucose-binding protein is different from that of the fucose-binding proteins of the other strains. A fuller understanding of adhesion mechanisms in C. albicans must await further characterization of these lectin-like proteins.

I.A.C. was the recipient of an SERC-CASE studentship awarded in collaboration with ICI Pharmaceuticals Division. We are grateful to ICI for additional financial support.

\section{REFERENCES}

Burnie, J. P., OdDS, F. C., Lee, W., Webster, C. \& Williams, J. D. (1985). Outbreak of systemic Candida albicans in intensive care unit caused by cross infection. British Medical Journal 290, 746-748.

Centeno, A., Davis, C. P., Cohen, M. S. \& Warren, M. M. (1983). Modulation of Candida albicans attachment to human epithelial cells by bacteria and carbohydrates. Infection and Immunity 39, 13541360.

Cinco, M., Banfi, E., Ruaro, E., Crevatin, D. \& CROTTI, D. (1984). Evidence for L-fucose (6-deoxy-Lgalactopyranose)-mediated adherence of Campylobacter spp. to epithelial cells. FEMS Microbiology Letters 21, 347-351.

Collins-Lech, C., Kalbfleisch, J. H., Franson, T. R. \& SoHNLE, P. G. (1984). Inhibition by sugars of Candida albicans adherence to human buccal mucosal cells and corneocytes in vitro. Infection and Immunity 46, 831-834.

CRITChleY, I. A. \& Douglas, L. J. (1987). Isolation and partial characterization of an adhesin from Candida albicans. Journal of General Microbiology 133, 629-636.

Diamond, R. D. \& KRZESICKI, R. (1978). Mechanisms of attachment of neutrophils to Candida albicans pseudohyphae in the absence of serum, and of subsequent damage to pseudohyphae by microbicidal processes of neutrophils in vitro. Journal of Clinical Investigation 61, 360-369.

Douglas, L. J. (1985). Adhesion of pathogenic Candida species to host surfaces. Microbiological Sciences 2, 243-247.

Douglas, L. J. (1987). Adhesion to surfaces. In The Yeasts, 2nd edn, vol. 2, pp. 239-280. Edited by A. H. Rose \& J. S. Harrison. London: Academic Press.

Douglas, L. J., Houston, J. G. \& McCourtie, J. (1981). Adherence of Candida albicans to human buccal epithelial cells after growth on different carbon sources. FEMS Microbiology Letters 12, 241243.

JoNES, G. W. \& FreTER, R. (1976). Adhesive properties of Vibrio cholerae: nature of the interaction with isolated rabbit brush border membranes and human erythrocytes. Infection and Immunity 14, 240-245.

JoNES, G. W. \& ISAACSON, R. E. (1983). Proteinaceous bacterial adhesins and their receptors. CRC Critical Reviews in Microbiology 10, 229-260.

LEE, J. C. \& KING, R. D. (1983). Characterization of
Candida albicans adherence to human vaginal epithelial cells in vitro. Infection and Immunity 41, 10241030.

Makrides, H. C. \& MacFarlane, T. W. (1983). An investigation of the factors involved in increased adherence of $C$. albicans to epithelial cells mediated by $E$. coli. Microbios 38, 177-185.

McCourtie, J. \& Douglas, L. J. (1981). Relationship between cell surface composition of Candida albicans and adherence to acrylic after growth on different carbon sources. Infection and Immunity 32, 12341241.

McCourtie, J. \& Douglas, L. J. (1984). Relationship between cell surface composition, adherence and virulence of Candida albicans. Infection and Immunity 45, 6-12.

Reinhart, H., Muller, G. \& Sobel, J. D. (1985). Specificity and mechanism of in vitro adherence of Candida albicans. Annals of Clinical and Laboratory Science 15, 406-413.

Rotrosen, D., Edwards, J. E., JR, Gibson, T. R., Moore, J. C., Cohen, A. H. \& Green, I. (1985). Adherence of Candida to cultured vascular endothelial cells : mechanisms of attachment and endothelial cell penetration. Journal of Infectious Diseases 152 , 1264-1274.

Sandin, R. L., Rogers, A. L., Patterson, R. J. \& BENEKE, E. S. (1982). Evidence for mannosemediated adherence of Candida albicans to human buccal cells in vitro. Infection and Immunity 35, 7985.

Segal, E., LeHrer, N. \& OfEK, I. (1982). Adherence of Candida albicans to human vaginal epithelial cells: inhibition by amino sugars. Experimental Cell Bio$\log y$ 50, 13-17.

SHARON, N. \& LIS, H. (1972). Lectins: cell-agglutinating and sugar-specific proteins. Science 177, 949959.

Sharon, N., Eshdat, Y., Silverblatt, F. J. \& OfEk, I. (1981). Bacterial adherence to cell surface sugars. In Adhesion and Microorganism Pathogenicity (Ciba Foundation Symposium no. 80), pp. 119-141. Edited by M. O'Connor, J. Whelan \& K. Elliott. London: Pitman Medical.

Sobel, J. D., Myers, P. G., KAYE, D. \& Levison, M. E. (1981). Adherence of Candida albicans to human vaginal and buccal epithelial cells. Journal of Infectious Diseases 143, 76-82. 